\title{
Consensus
}

Volume 19

Issue 1 Martin Luther and Spirituality

Article 15

5-1-1993

\section{The Double Vision: Language and Meaning in Religion}

H. Victor Froese

Follow this and additional works at: http://scholars.wlu.ca/consensus

\section{Recommended Citation}

Froese, H. Victor (1993) "The Double Vision: Language and Meaning in Religion," Consensus: Vol. 19 : Iss. 1 , Article 15. Available at: http://scholars.wlu.ca/consensus/vol19/iss1/15

This Book Reviews is brought to you for free and open access by Scholars Commons @ Laurier. It has been accepted for inclusion in Consensus by an authorized editor of Scholars Commons@ Laurier. For more information, please contact scholarscommons@wlu.ca. 
need for North American Christians to re-create a new liberation theology after correctly hearing Third World theologies and taking ownership of the oppression we have caused the Two-Thirds World. This new liberation theology has already taken wing with a growing number of contextual theologies. McAfee Brown sums up aptly the significance of Gustavo Gutierrez: "the total congruence between what he writes and what he lives remains his supreme contribution to the rest of us" (205).

Pablo Richard gives kudos to Gutierrez as a continuing source of strength, vision and inspiration for liberation theologians whenever they have grown weary and disillusioned. He predicts progress in biblical studies because of liberation hermeneutics. He also hopes for a more equal, respectful relationship between intellectuals and the common people. Richard believes that the only future for theology is liberation theology and the next century belongs to the Two-Thirds World.

This volume is recommended reading for seminarians, professors, pastors, church leaders and laity. It stimulates, critiques and challenges the reader by raising important theological questions in such a way as to engage us in continuing debate, dialogue-as well as action.

Garth Wehrfritz-Hanson

Shepherd of the Hills Lutheran Church

Calgary, Alberta

\section{The Double Vision: Language and Meaning in Reli- gion \\ Northrop Frye}

Toronto: University of Toronto Press, 1991

88 pages

The Double Vision gives us the parting words of Canada's premier literary critic and educator. An ordained United Church minister, Northrop Frye (1912-1991) was perhaps best known for his internationally acclaimed Fearful Symmetry (1947) and Anatomy of Criticism (1957). He more recently gained recognition for his studies of the impact of the Bible on Western literature, The Great Code (1982) and Words With Power (1990). In The Double Vision (title borrowed from William Blake), Frye summarizes his understanding of faith, an understanding implied throughout his writings but given perhaps its most explicit expression here. On this subject, as on so many others, Frye is refreshingly original.

What makes Frye's approach to the Bible (and, hence, faith) "original" is, ironically, also what links him to classical Christianity: both exhibit a stubborn indifference to the question of the historical reliability of biblical narratives and intense preoccupation with their literary, metaphorical 
qualities. To be sure, classical theologians assumed historical reliability. Nevertheless, the weight of their theology rested on a literary reading of the Scriptures that is closer to Frye's poetics than either to historical criticism or to fundamentalist literalism.

Frye's own "imaginative literalism" is consistent with his view of education. Rejecting stricter forms of catechesis, Frye insists that "teaching by myth and metaphor is the only way of educating a free person in spiritual concerns" (18). Only an "imaginative" (rather than "descriptive") literalism will elicit a free, active response to spiritual vision the Scriptures impart.

It may be disconcerting to some that Frye resists any synthesis of the two approaches and does so unequivocally. Yet his motive is difficult to impugn:

The question often arises, Why can't we have it both ways? Why can't there be a definitive literal-descriptive dimension along with a spiritual vision of it? The reason, apart from the contradictions and inconsistencies involved, is that the former is a passive response and the latter an active one, and if they were both there the passive one would take over and eliminate the active one... The "both ways" we have, therefore, are only the alternatives of the choice between using the Gospels as spiritual batteries, so to speak, for charging one's spiritual energies, and looking at them objectively as aesthetic productions. (72)

The Double Vision is also likely to discomfort some readers because it casually employs such inflammatory terms as "myth", "imagination", and even "illusion" when explaining Christian faith. Frye has his own definitions of these terms, however, and those who read carelessly will come away with a mistaken understanding of his views.

But even when properly understood, Frye's conception of faith will not satisfy the sentimental or nostalgic. "The truth" in spiritual matters is not available to us (20). Faith therefore comes with no guaranteesindeed, involves risk and adventure (72). A faith of guarantees fosters bland complacency at best and violent fanaticism at worst. For Frye, the only faith worth holding is one that arouses and sustains the desire of human beings to express their most creative (i.e., divine) energies. He leaves it to those who call themselves Christians to demonstrate that Christian faith is in that number.

H. Victor Froese

London, Ontario 